\title{
PRODUCT AND SERVICE RELIABILITY ESTIMATION
}

\author{
UDC: 658.8:658.562 \\ Original Scientific Paper \\ Branko Z. POPOVIĆ ${ }^{1}$ \\ ${ }^{1}$ University of Belgrade, Mechanical Faculty, 11000 Belgrade, Kraljice Marije 16, Republic of Serbia \\ E-mail: branko@popovic.org
}

Paper received: 22.10.2019.; Paper accepted: 13.11.2019.

\begin{abstract}
Some manufacturers in Europe neglect to determine the reliability of products and services, although reliability is a very significant magnitude of the quality of process results (semi-finished product, product, documentation, service). They usually declare the amount of reliability the way their competitor did, not realizing the real differences between the individual process results, which certainly causes unnecessary costs. When they declare higher reliability, then losses occur due to the high cost of customer complaints, and when they declare lower reliability, then losses arise due to large losses in demand for the results of market processes. In America, a different approach is taken to consider reliability, which involves designing, planning, and verifying the reliability of process results, using special computer programs and electronic computers. Reliability design allows defining the reliability of systems and components of process results, according to the requirements of critical quality characteristics, thereby achieving the required level of quality. Reliability planning enables the preparation of reliability checks by developing a test plan, reliability and warranty plan, a forecasting plan and a product or service guarantee plan. The reliability check makes it possible to determine the true reliability of the results of the process after experimental testing, under long-term real conditions or under short-term accelerated conditions, with the application of certain higher loads. This paper discusses the elements of stability and reliability and proposes the necessary procedure for selecting the design, planning and checking the reliability of process results. Using this selection, the procedures for designing, planning, and verifying the reliability of certain process results are shown here.
\end{abstract}

Keywords: Systems engineering; Reliability engineering; Reliability.

\section{INTRODUCTION}

Reliability is the likelihood of a condition where the result of the process has no failures or is stable, with characteristics of availability quality, reliability, and sustainability, durability, safety and security. Cancellation is a condition or event that is negativity of a result, which can be considered the opposite of a desired, planned or expected result. Persistence is the state of the result of a process when it works without failure. Quality characteristics include many important features that define the quality of process results. Quality is the level to which a set of quality characteristics of the process results meets the planned requirements. (Popović, 2009, 2016, 2017).

The term reliability was first mentioned in 1816 by the English philosopher S. T. Coleridge (1772-
1834) who, before the Second World War, was associated mainly with repeatability, when the same results were obtained more than once. In the 1920s, reliability was promoted by US statistician Dr. W. A. Shewhart (1891-1967) through statistical control of the process. At that time, the Swedish engineer W. Weibull (1887-1979) studied the statistical models of fatigue and propagation of explosive waves, and in 1939 discovered the Weibull statistical distribution of reliability. (Popović, 2018; 2019; Popović, \& Ivanović, 2011).

More recently, product reliability has been recognized as the reliability of systems and components, that is, the likelihood of system and component states when there is no failure. The reliability study is based on systems engineering and reliability engineering. Systems Engineering is an interdisciplinary field of engineering and 
engineering management that focuses on the design and management of complex systems, throughout their tenure. Reliability engineering is the discipline of system engineering, which encompasses system reliability and process result components, with the goals of applying engineering knowledge and specialist techniques, to prevent or reduce the likelihood or frequency of failure, identify and remedy the cause of failure, and determine how to deal with failure by applying assessment methods probable reliability, new projects, and reliability data analysis. A special approach to reliability considerations is being undertaken in relation to Europe in America, which involves designing, planning and verifying the reliability of process results, using special computer programs and electronic computers. (Ebeling, 1997; Morris, et al., 1995; Musa, 2005; Samaniego, 2007; Buede, \& Miller, 2016)

\section{METHODOLOGY}

The application of product and service reliability checks depends on the data collected, needs expressed, desirable accuracy and time available. In the implementation of the reliability check, the recommended procedure for selecting the reliability of the process results according to Figure 1. can be used. checking the reliability of the process results.

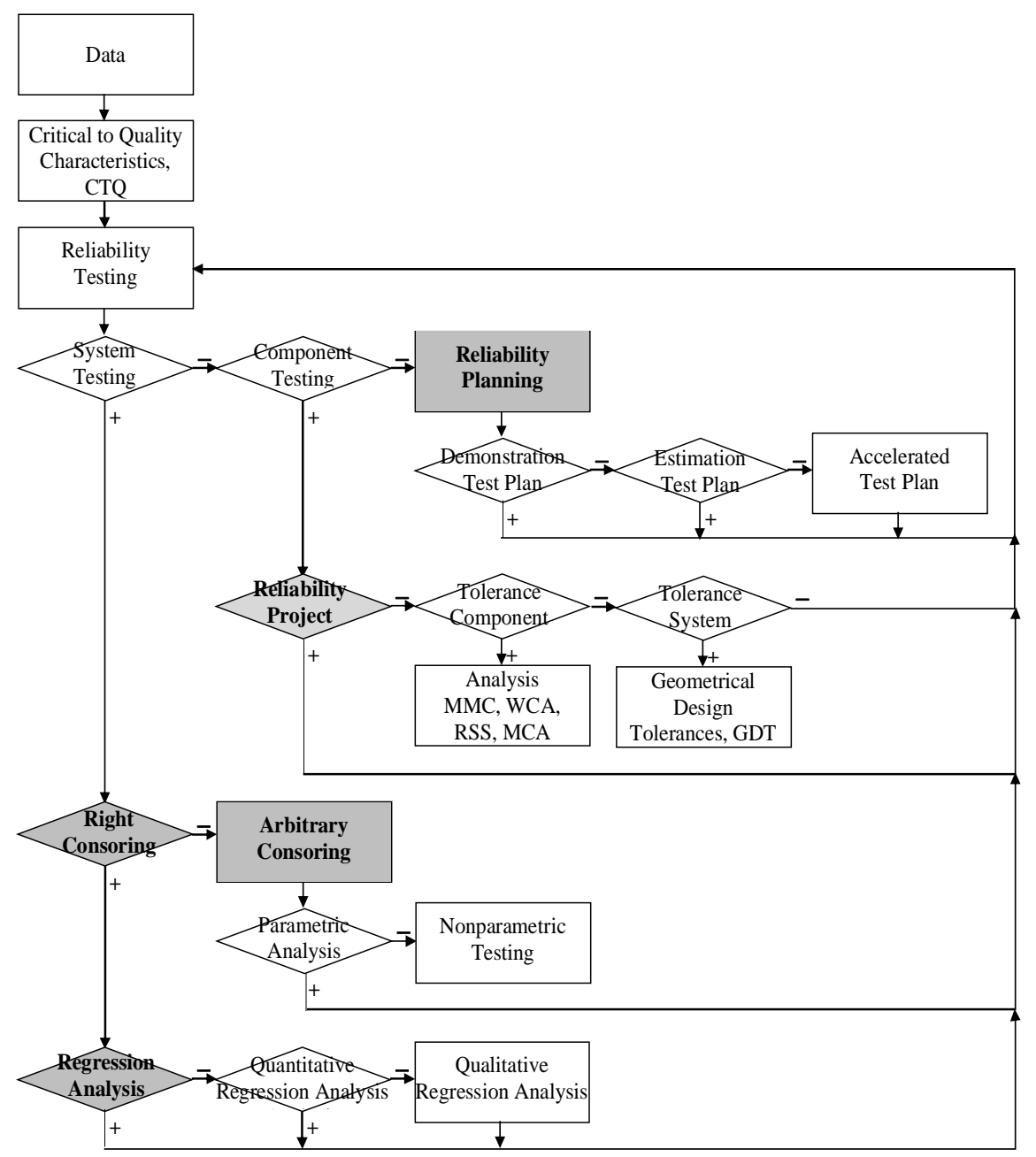

Figure 1: Recommended choice of considering the reliability of process results

Based on the data collected, critical quality characteristics are determined to calculate the reliability of the process results, and then the system or component is thoroughly considered, applying design, planning, and validation processes, using specific computer programs (Neubeck, 2004).

Reliability design involves tolerating components or systems using the necessary analyzes: maximum 
material (MMA), worst case (WCA), square root sum (RSS), Monte Carlo (MCA), and dimension and tolerance (GD\&T). Reliability Planning allows you to plan for previous tests, plan for reliability assessment, and schedule possibly accelerated high load reliability checks. Testing the reliability of process results allows for limited or unlimited validation, guarantee calculations, and regression reliability analysis.

Limited reliability checks are performed when errors occur after the planned or prescribed confidence limit, before the result of the procedure is invalid, by parallel analysis and non-parametric reliability distribution testing. An unlimited reliability check is performed when failures occur before or between two planned or prescribed confidence limits. Process performance checking allows predicting reliability with a rational allocation of production costs and addressing potential consumer process results. Regression reliability analysis includes quantitative regression analysis with continual variable size and qualitative regression analysis with a discrete variable or categorical variable (Popovic, \& Klarin, 2005).

\section{DESIGNING RELIABILITY OF PRODUCTS AND SERVICES}

Reliability design allows defining the reliability of systems and components of process results, according to the requirements of critical quality characteristics (CTQ), which define the critical level of quality of the entire system of process results, including the reliability of components. Designing component reliability most often requires the analysis of tolerances (MMA, WCA, RSS, MCA), the determination of tolerances (GD\&T), and the prediction of the geometric sizes of the components, which ensure the calculation of the stability and reliability of the components (Nelson, 2004; Neubeck, 2004; Rouaud, 2013; Samaniego, 2007).

According to International Standards (ISO) the surfaces, the position of surfaces, surface product geometry includes lengths, angles, line, surface geometry includes lengths, angles, line, surface and location sizes, the shape of lines and roughness and size on the principle of maximum material. The geometries of the product are not solid but must necessarily have certain tolerances or tolerances, between the upper and lower boundaries. In designing the reliability of systems and components, it is particularly important: understanding the symbols and terminology for interpreting component tolerances, tolerating component dimensions, and developing special transfer functions of geometric quantities, with the analysis of tolerance zones. The transfer function defines the critical relationships of geometric quantities between individual components of the process result system. The geometric tolerance zone defines the sizes and position relationships of individual dimensions, especially when at the maximum of the material.

The Maximum Material Condition (MMC) tolerance analysis allows for a certain tolerance of shape or position to be exceeded at the calculus of material savings, which is very useful in real production. If the tolerance for the Hole and Shaft assembly is prescribed, then the Hole position tolerance is also prescribed, while the MMC is equal to the lower limit Hole diameter and the upper limit Hole diameter. Each increase in the diameter Hole causes a change in the position tolerance Hole.

E.g. The design of the Hole and Shaft assembly with the MMC condition in Figure 2. with a Hole tolerance of $0.350 \mathrm{~mm}$ to $0.360 \mathrm{~mm}$ and a Shaft position tolerance of $0.010 \mathrm{~mm}$, will find a large number of good solutions, despite production variations:

- the dashed circle represents the MMC for both parts, the shaft surface must be entirely inside the notched circle and the hole surface must be completely outside the notched circle,

- the calculation of the maximum distance between the hole and the axis, represented by $\mathrm{Y}$ which is here the transfer function for $\mathrm{Y}$ in terms of hole diameter and axis $\left(H_{\text {Diam }}, S_{\text {Diam }}\right)$ and the actual positions represented by $\mathrm{X}$ and $\mathrm{Y}$ coordinates $\left(H_{T P X}, H_{T P Y}, S_{T P X}, S_{T P Y}\right)$ :

$$
Y=\frac{H_{\text {Diam }}-S_{\text {Diam }}}{2}+\sqrt{\left(H_{T P X}-S_{T P X}\right)^{2}+\left(H_{T P Y}-S_{T P Y}\right)^{2}},
$$


- constructing a spreadsheet of Crystal Ball® assumptions and forecasts as shown in Figure 3. where column F contains all the formulas used in column $\mathrm{E}$,

- determination of each of the six assumptions with a uniform distribution between the tolerance limits,

- determining a cell with a formula that is TRUE only when the hole is in geometric tolerance, that is, this cell is correct only if:

$$
\sqrt{H_{T P X}^{2}+H_{T P Y}^{2}} \leq \frac{H_{\text {Diam }}-0.350}{2} \text {, }
$$

- this cell was named HoleInTol and used in formulas for E5-E7 cells, which only show hole-tolerant dimensions,

- taking the same steps for axle characteristics,
- entering a formula into the cell to calculate Y, based on the formulas in column E (Samaniego, 2007).

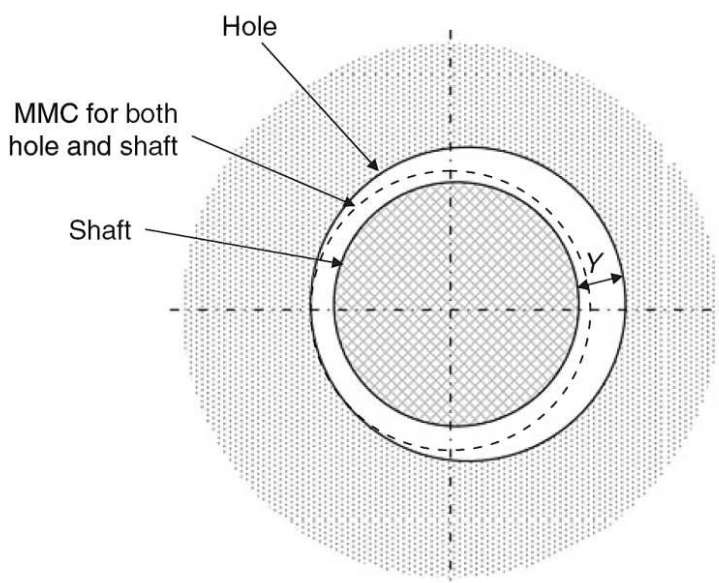

Figure 2: Assembly of hole and shaft sizes

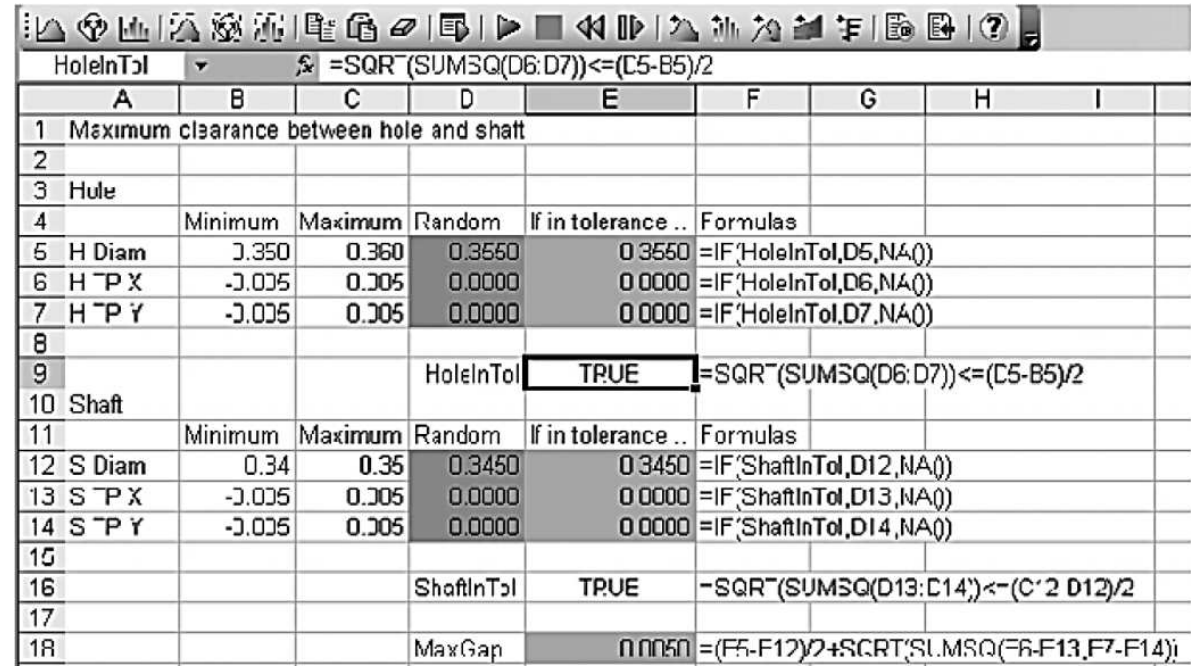

Figure 3: Microsoft Excelworksheet with Crystal Ball analyze analysis data

\section{RESULT OF PRODUCT AND SERVICE RELIABILITY DESIGN}

The application of the reliability procedure enables the design of products with optimal survival and reliability values, using component or system tolerance with the necessary analysis (MMA, WCA, RSS, MCA) and dimension design system and tolerance (GD\&T).
E.g. obtained probability histogram and maximum distance frequency in Figure 4. with calculated values after 30,400 simulations, which lasted up to a precision estimate for $1 \%$ of product assemblies with the final result that only 2,044 good cases were identified, when the openings and shafts were within the appropriate tolerance zone. 


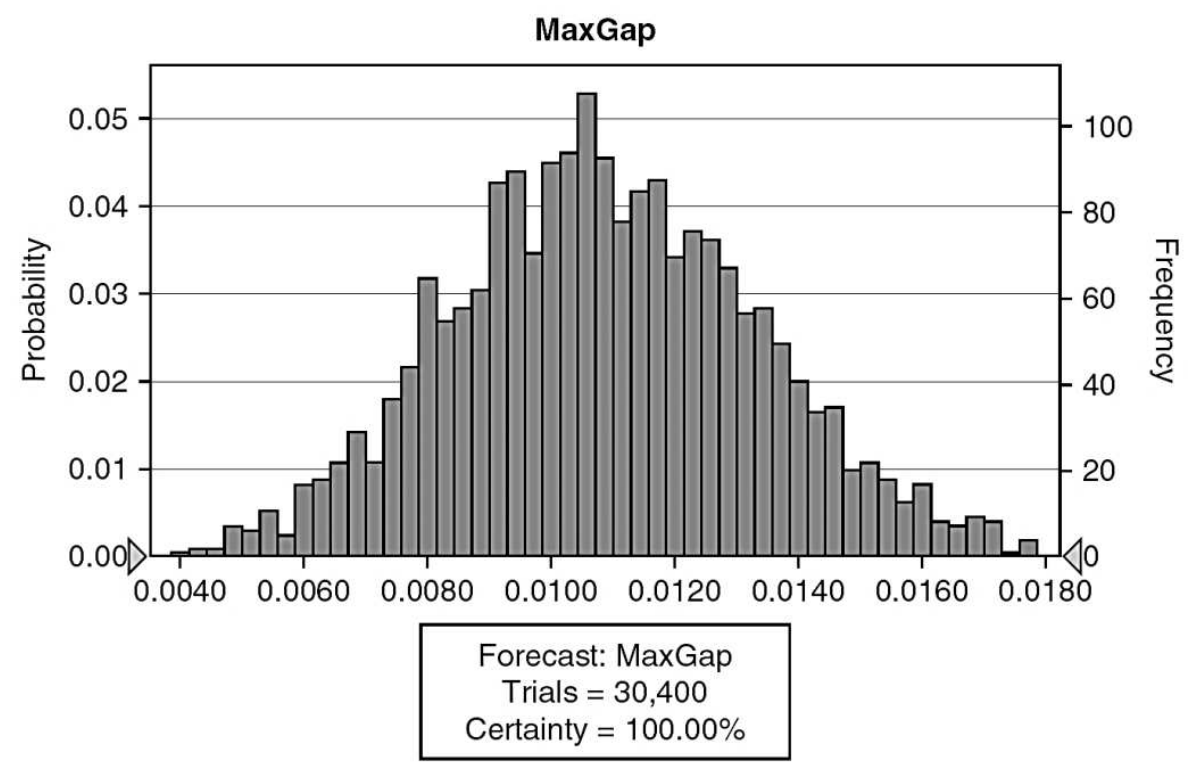

Figure 4: Scatter histogram obtained with calculated GAP values

\section{PLANNING OF PRODUCT AND SERVICE RELIABILITY}

Applying the reliability planning process enables you to obtain products with optimal survival and reliability values, using the planning of the development of Demonstration test plans, Test plans, and Accelerated life test plans.
E.g. when planning an accelerated product reliability check under normal operating conditions at $55^{\circ} \mathrm{C}$ and at worst operating conditions at $85^{\circ} \mathrm{C}$, after reviewing every two days, the data collected in Table 1 . were obtained, and a 5\% reliability plan was planned and then implementing a computer program Minitab®:

Table 1: Product failure data collected

\begin{tabular}{|r|r|r|r|r|r|r|}
\hline & \multicolumn{1}{c|}{ C1 } & \multicolumn{1}{c|}{ C2 } & \multicolumn{1}{c|}{ C3 } & \multicolumn{1}{c|}{ C4 } & C5 \\
\hline & StartTime & EndTime & Count & Temp & NewTemp \\
\hline 1 & 0 & 2 & 0 & 125 & 55 \\
\hline $\mathbf{2}$ & 2 & 4 & 1 & 125 & 85 \\
\hline 3 & 4 & 6 & 1 & 125 & \\
\hline 4 & 6 & 8 & 0 & 125 & \\
\hline $\mathbf{5}$ & 8 & 10 & 0 & 125 & \\
\hline 6 & 10 & 12 & 1 & 125 & \\
\hline 7 & 12 & 14 & 1 & 125 & \\
\hline $\mathbf{8}$ & 14 & $*$ & 46 & 125 & \\
\hline $\mathbf{9}$ & 0 & 2 & 5 & 150 & \\
\hline 10 & 2 & 4 & 2 & 150 & \\
\hline 11 & 4 & 6 & 2 & 150 & \\
\hline 12 & 6 & 8 & 2 & 150 & \\
\hline
\end{tabular}

\begin{tabular}{|r|r|r|r|r|}
\hline & $\begin{array}{c}\text { C1 } \\
\text { StartTime }\end{array}$ & \multicolumn{1}{c|}{ C2 } & \multicolumn{1}{c|}{ C3 } & \multicolumn{1}{c|}{ C4 } \\
\hline 13 & 8 & 10 & 2 & 150 \\
\hline 14 & 10 & 12 & 2 & 150 \\
\hline 15 & 12 & 14 & 3 & 150 \\
\hline 16 & 14 & $*$ & 34 & 150 \\
\hline 17 & 0 & 2 & 8 & 175 \\
\hline 18 & 2 & 4 & 6 & 175 \\
\hline 19 & 4 & 6 & 5 & 175 \\
\hline 20 & 6 & 8 & 4 & 175 \\
\hline 21 & 8 & 10 & 3 & 175 \\
\hline 22 & 10 & 12 & 5 & 175 \\
\hline 23 & 14 & $*$ & 15 & 175 \\
\hline 24 & 12 & 14 & 5 & 175 \\
\hline
\end{tabular}

- the program is started (Stat> Reliability / Survival> Test Plans> Accelerated Life Testing),

- the collected data is entered and results are obtained in the form of tables and diagrams. (Levin et al., 2001),

- the first table in Figure 5. are obtained showing the method (maximum likelihood method), the type of distribution used (Weibull), values (P) equal to zero, therefore rejecting the null hypotheses $\mathrm{H}_{0}\left(\mathrm{P}>\alpha \Rightarrow \mathrm{H}_{0}\right)$ and accept alternative hypotheses $\mathrm{H}_{1}\left(\mathrm{P} \leq \alpha \Rightarrow \mathrm{H}_{1}\right)$ that temperatures affect reliability $(\alpha=0.05)$,

- second table in Figure 6. shows the product reliability results obtained at an operating temperature of $55^{\circ} \mathrm{C}$ and an elevated temperature of $85^{\circ} \mathrm{C}$ 


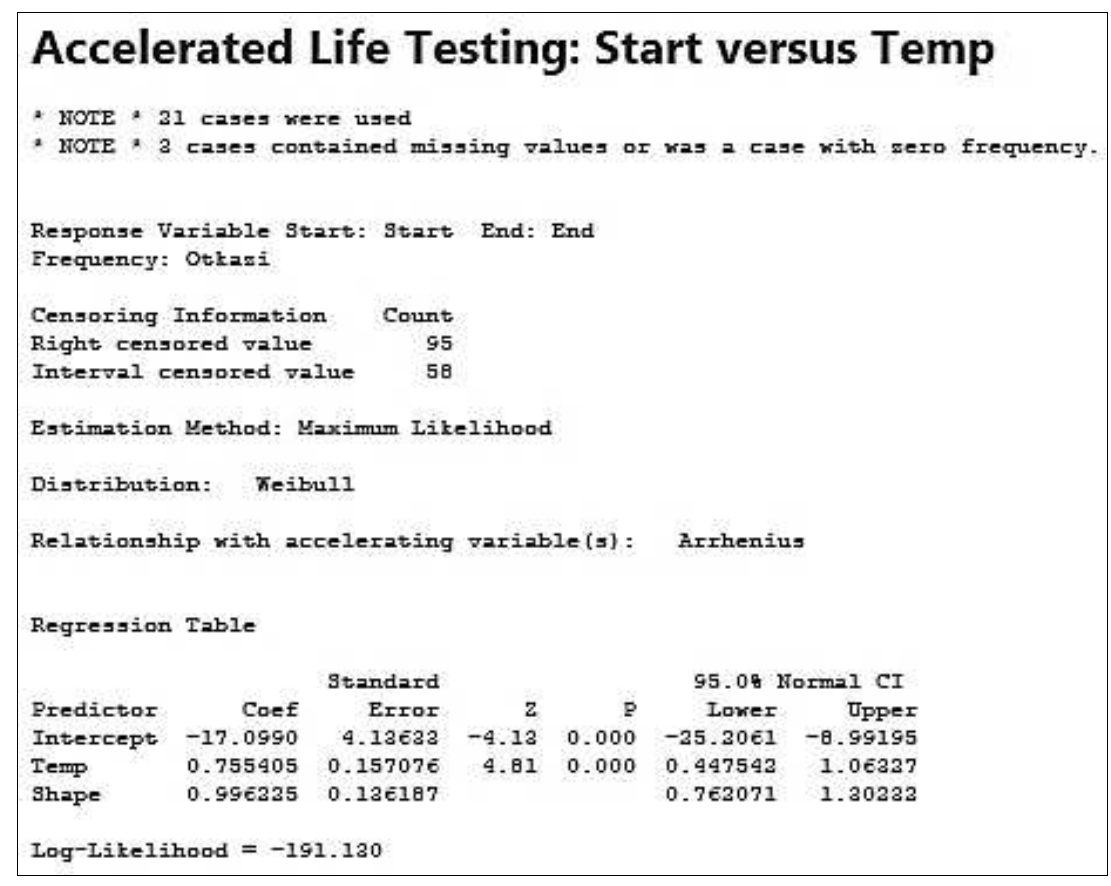

Figure 5: The first table of product reliability results

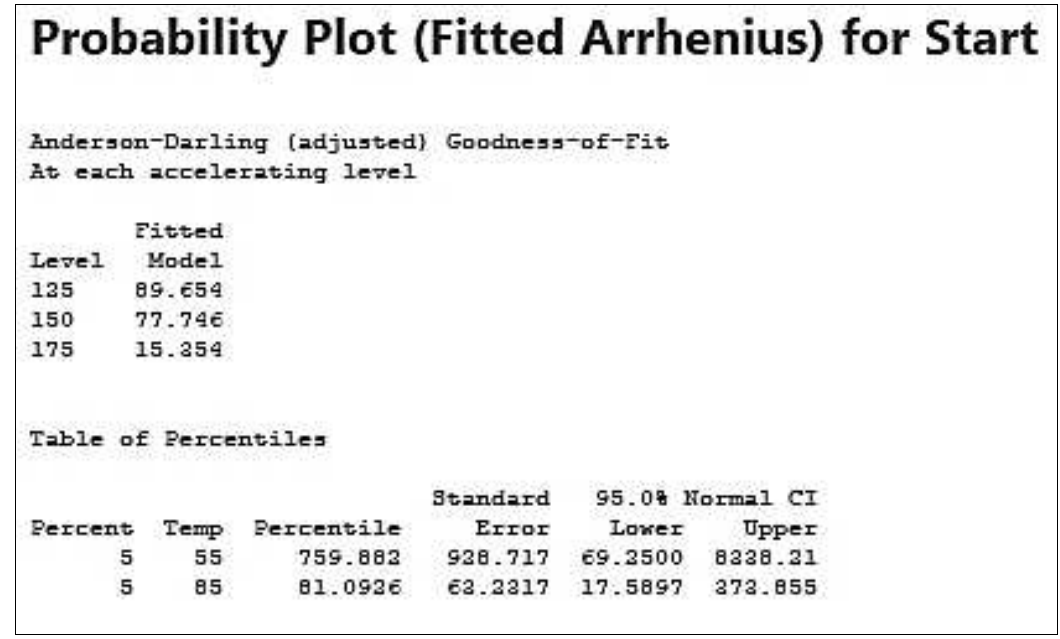

Figure 6: The second table of product reliability results

\section{RESULT OF PRODUCT AND SERVICE RELIABILITY PLANNING}

The application of the reliability planning process enables the production of products with optimal survival and reliability values, the development of Demonstration test plans, Test plans, and Accelerated life test plans.

E.g. when planning an accelerated product reliability check under normal operating conditions at $55^{\circ} \mathrm{C}$ and under worst conditions at $85^{\circ} \mathrm{C}$, the data obtained show:
- at a design temperature of $55^{\circ} \mathrm{C}$, all $5 \%$ of products will cancel after approximately 760 days, which is just over 2 years and

- at a maximum temperature of $85^{\circ} \mathrm{C}$, all $5 \%$ of the product will cancel after approximately 81 days.

The obtained probability diagram of the accelerated product reliability check of Figure 7 . and Figure 8. shows that all points of the data collected approximately follow straight lines at temperatures of $125^{\circ} \mathrm{C}, 150^{\circ} \mathrm{C}$ and $175^{\circ} \mathrm{C}$ and the conclusions reached (Ebeling, 1997): 
- the appropriateness of the model assumption for the application of accelerated product reliability checking is confirmed and

- all points at $125^{\circ} \mathrm{C}$ are within the boundary lines, which confirms the good reliability of the product and at higher temperatures.

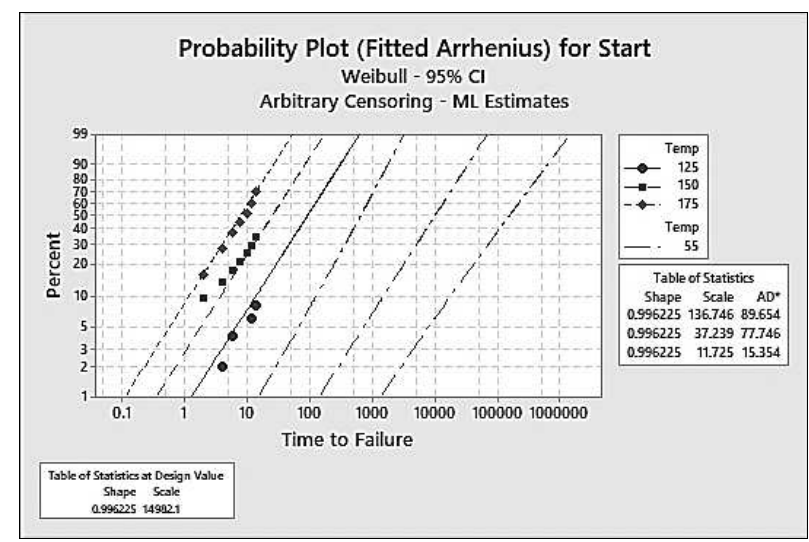

Figure 7: Probability diagram of an accelerated product reliability check

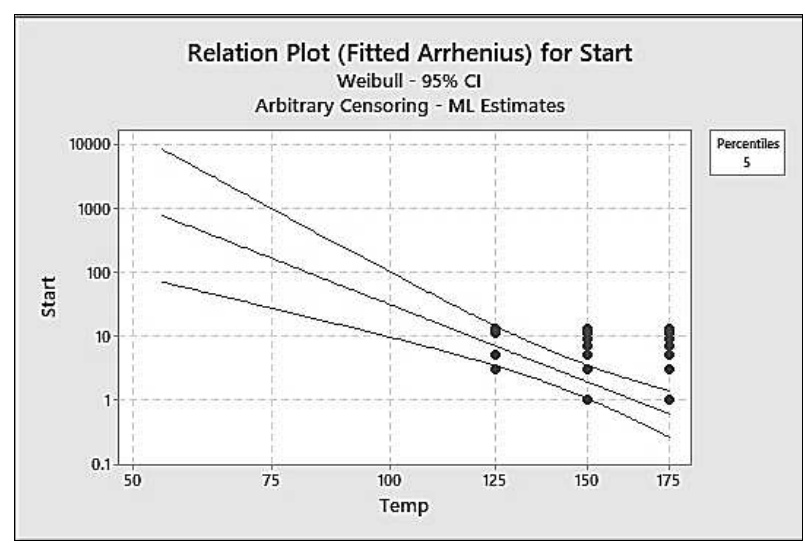

Figure 8: Probability diagram of the start of the Appliance reliability check

\section{ESTIMATION OF PRODUCT AND SERVICE}

Reliability testing makes it possible to determine the true reliability of systems and components, after experimental testing, in long-term realistic conditions or in short-term accelerated conditions, with the application of certain higher loads.Censorship verification of correct censorship is made when errors occur outside the planned or prescribed confidence limits, before the product and service fail, by parallel analysis and nonparametric reliability distribution testing. Arbitrary censorship reliability checks are performed when errors occur before or between two planned or prespecified boundaries. reliability.
Product warranty planning and forecasting enable rational allocation of production costs and resolution of problems with potential cancellation of process results to consumers, avoiding wasteful over-warranty planning and inadequate underwarranty planning. Regression reliability analysis involves quantitative regression analysis with continuous variable and qualitative regression analysis with a discrete variable or categorical variable size (Kvaloy, \& Lindqvist, 1998; O'Connor, 2002).

E.g. When planning a warranty for the delivery of products with fragile parts, according to the information collected in Table 2, the Minitab computer program is used to plan and anticipate warranties:

- an appropriate data table is created according to Table 3. according to the year of delivery,

- a warranty planning program is launched (Stat> Reliability / Survival> Warranty Analysis> Warranty Pre-Procedure Information),

- collected data is entered, and

- the results are obtained in the form of tables and diagrams.

Table 2: Collected delivery data of products with brittle parts

\begin{tabular}{|r|c|c|c|r|r|r|}
\hline+ & C1 & C2 & C3 & C4 & \multicolumn{1}{c|}{ C5 } & \multicolumn{1}{c|}{ C6 } \\
\hline & Time & Units & Failure 2015 & Failure 2016 & Failure 2017 & Failure 2018 \\
\hline 1 & 2015 & 1000 & 5 & 6 & 10 & 3 \\
\hline 2 & 2016 & 1500 & & 8 & 13 & 4 \\
\hline 3 & 2017 & 2300 & & & 20 & 5 \\
\hline 4 & 2018 & 2500 & & & & 6 \\
\hline
\end{tabular}

\section{RESULT OF ESTIMATION PRODUCT AND SERVICE RELIABILITY}

Product warranty planning and forecasting enable rational allocation of production costs and resolution of problems with potential cancellation of process results to consumers, avoiding wasteful over-warranty planning and inadequate underwarranty planning. (Modarres, Kaminskiy, \& Krivtsov, 1999).

E.g. When planning a guarantee for the delivery of products with fragile parts, the results obtained show:

- the obtained Figure 9. gives the parameters of the applied Weibull reliability distribution, the quantities delivered (7,300 pieces) and the total number of refractions (80), 
- after 4 deliveries, the estimated number of fractures is between 184 and 242 pieces $(184.749 \div 242.915)$, with a $95 \%$ confidence level,

- the diagram in Figure 10. shows the change in the number of fractures of the parts with the center line and the boundary lines,
- the possibility of planning a guarantee of delivery of $7,300 / 184=39.673 \mathrm{pcs}$ or $(7,300 / 242=30.165 \mathrm{pcs})$, with a guarantee of delivery of parts of $30 \%$.

Table 3: Suitable delivery table for products with brittle parts

\begin{tabular}{|r|c|c|c|r|r|r|r|r|r|}
\hline+ & C1 & C2 & \multicolumn{1}{c|}{ C3 } & \multicolumn{1}{c|}{ C4 } & \multicolumn{1}{c|}{ C5 } & \multicolumn{1}{c|}{ C6 } & \multicolumn{1}{c|}{ C7 } & \multicolumn{1}{c|}{ C8 } \\
\hline & Time & Units & Failure 2015 & Failure 2016 & Failure 2017 & Failure 2018 & Start time & End time & Frequencies \\
\hline 1 & 2015 & 1000 & 5 & 6 & 10 & 3 & 0 & 1 & 39 \\
\hline 2 & 2016 & 1500 & & 8 & 13 & 4 & 1 & 2 & 24 \\
\hline 3 & 2017 & 2300 & & & 20 & 5 & 2 & 3 & 14 \\
\hline 4 & 2018 & 2500 & & & & 6 & 3 & 4 & 3 \\
\hline 5 & & & & & & & 1 & $*$ & 2494 \\
\hline 6 & & & & & & & 2 & $*$ & 2275 \\
\hline 7 & & & & & & & 3 & $*$ & 1475 \\
\hline 8 & & & & & & & 4 & $*$ & 976 \\
\hline
\end{tabular}

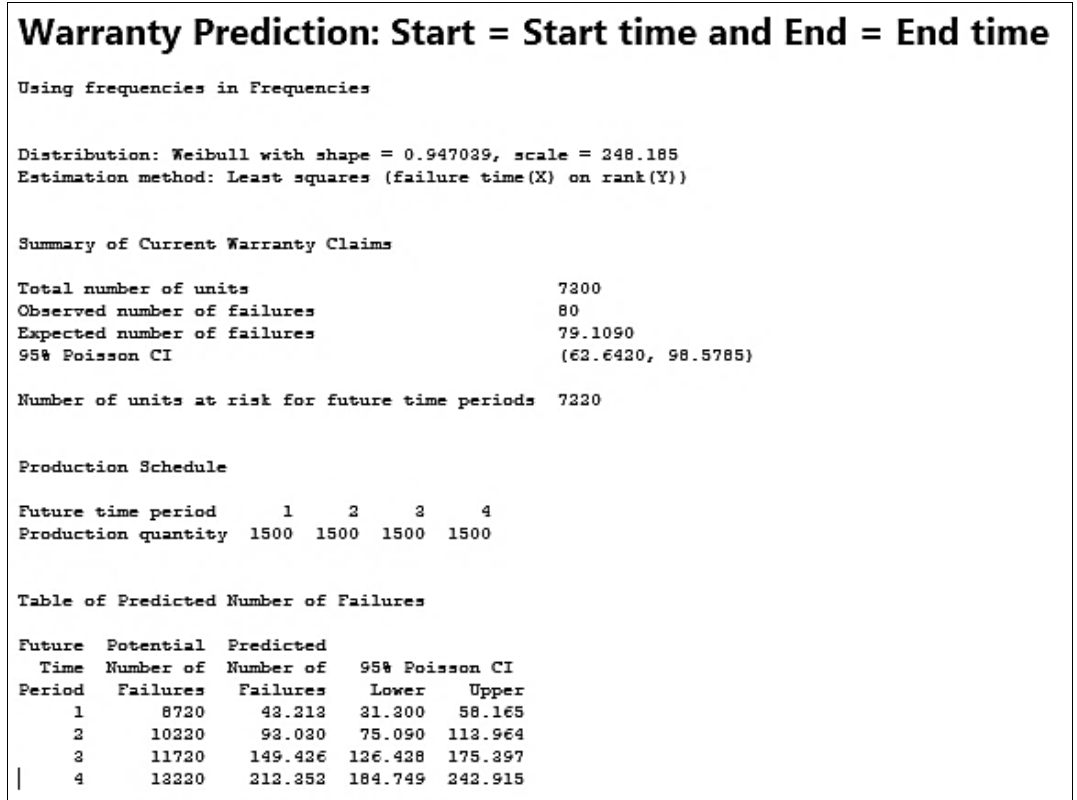

Figure 9: Forecasting the delivery of products with brittle parts

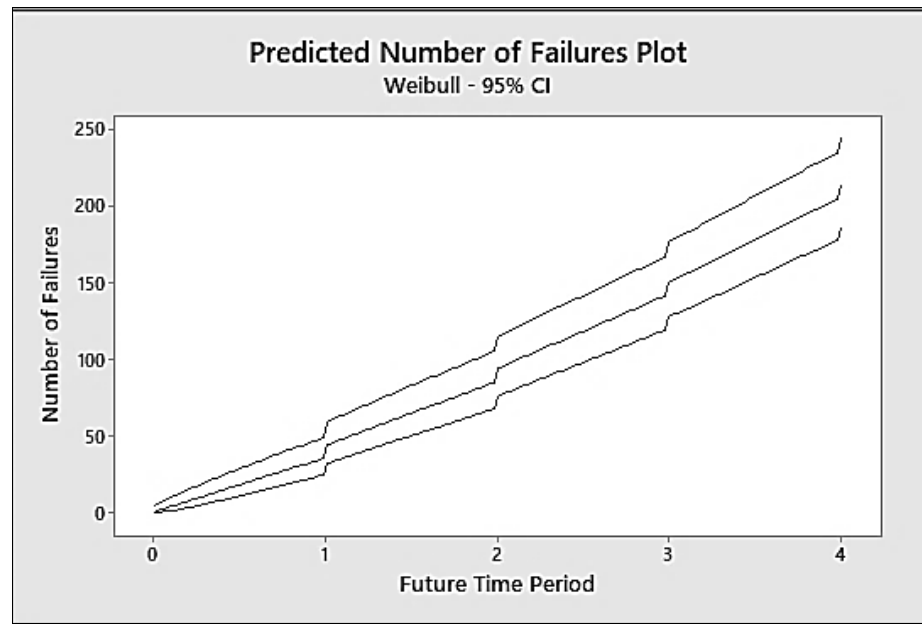

Figure 10: Delivery prediction diagram of products with brittle parts 


\section{CONCLUSIONS}

In Europe, the reliability of process results is sometimes neglected, although reliability is a very significant magnitude of the quality of process results. Usually, reliability is declared, as a competitor did, without realizing the real differences between the individual qualities of the process results. In America, a different approach is taken to consider reliability, which involves designing, planning, and verifying the reliability of process results, using special computer programs and electronic computers.

Reliability design allows defining the reliability of systems and components of process results, according to the requirements of critical quality characteristics. Reliability planning enables the preparation of reliability checks by designing a test plan for reliability, a plan for assessing reliability and guarantees, a plan for predicting reliability, and a plan for guarantees of process results. Reliability testing enables the determination of the true reliability of systems and components, after experimental testing in long-term real-world conditions or in short-term accelerated conditions, with the application of certain higher loads.

\section{REFERENCES}

Buede, D.M.,\& Miller, W. D. (2016).The Engineering Design of Systems: Models and Methods (3rd Ed.). John Wiley and Sons.

Ebeling, Ch. E. (1997). An Introduction to Reliability and Maintainability Engineering. Boston: McGrawHill Companies, Inc.

Kvaloy, J. T., \& Lindqvist, B. H. (1998). TTT-based tests for trend in repairable systems data. Reliability Engineering \& System Safety, 60(1), 13-28.

Levin, D.M., Ramsey, P.P., \& Smidt, R. K. (2001). Applied Statistics: Using Microsoft Excel \& Minitab. Pearson.
Modarres, M., Kaminskiy, M., \& Krivtsov, V. (1999). Reliability Engineering and Risk Analysis: A Practical Guide, CRC Press.

Morris, S., Dudley, B., Caroli, J., MacDiarmid, P., Nicholls, D., Coppola, A., ... \& Farrell, J. (1995). Reliability toolkit: Commercial practices edition. Reliability Analysis Center and Rome Laboratory, New York.

Musa, J. (2005). Software Reliability Engineering: More Reliable Software Faster and Cheaper (2nd. Ed.) AuthorHouse.

Nelson, W. B. (2004). Accelerated Testing - Statistical Models, Test Plans, and Data Analysis. New York: John Wiley \& Sons.

Neubeck, K. (2004). Practical Reliability Analysis. New Jersey: Prentice Hall.

O'Connor, P. (2002). Practical Reliability Engineering (4th Ed.). New York: John Wiley \& Sons.

Popović, B. (2016). Sistem šest sigma-Six Sigma System. Beograd: Akademska misao.

Popović, B. (2017). Simulacija poslovnih procesaSimulation of business procesess. Beograd: Akademska misao.

Popović, B. (2018). Optimalni troškovi kvaliteta Optimall costs of quality. Beograd: Akademska misao.

Popović, B. (2019). Optimalno rešavanje problema (Optimal solving of problems). Beograd: Akademska misao.

Popović, B., \& Ivanović, G. (2011). Sistem šest sigma u projektovanju rezultata procesa-Design for Six sigma. Beograd: Mašinski fakultet.

Popović, B., \& Klarin, M. (2009). Upravljanje proizvodnjom i usluživanjem (Operations Management). Beograd: Mašinski fakultet.

Rouaud, M. (2013). Probability, Statistics and Estimation. Retrieved from: www.incertitudes.fr/book

Samaniego, F. J. (2007). System Signatures and their Applications in Engineering Reliability. New York: Spinger.

\title{
PROCENA POUZDANOSTI PROIZVODA I USLUGA
}

\begin{abstract}
Neki proizvođači u Evropi zanemaruju određivanje pouzdanosti proizvoda i usluga, iako je pouzdanost veoma značajna veličina kvaliteta rezultata procesa (poluproizvod, proizvod, dokumentacija, usluga). Oni obično deklarišu iznos pouzdanost onako kao što je to uradio njihov konkurent, ne uviđajuči stvarne razlike između pojedinih kvaliteta rezultata procesa, što sigurno uzrokuje nepotrebne troškove. Kada se deklariše viša pouzdanost tada nastaju gubici zbog velikih troškova reklamacija kupaca a kada se deklariše niža pouzdanost onda nastaju gubici zbog velikih gubitaka tražnje rezultata procesa na tržištu. U Americi se vrši drugačiji pristup razmatranja pouzdanosti, koji obuhvata projektovanje, planiranje i proveravanje pouzdanosti rezultata procesa, pomoću posebnih računarskih programa i elektronskih računara. Projektovanje pouzdanosti (Reliability Design) omogućava definisanje pouzdanosti sistema i komponenata
\end{abstract}


rezultata procesa, prema zahtevima kritičnih karakteristika kvaliteta (Critical To Quality characteristics, CTQ), čime se postiže potrebni nivo kvaliteta. Planiranje pouzdanosti (Reliability test plan) omogućava pripremu proveravanja pouzdanosti izradom plana probnih provera, plana procene pouzdanosti i garancija, plana predviđanje i plana garancija proizvoda ili usluga. Proveravanje pouzdanosti (Reliability Testing) omogućava utvrđivanje stvarne pouzdanosti rezultata procesa posle eksperimentalnih ispitivanja, u dugotrajnim realnim uslovima ili u kratkotrajnim ubrzanim uslovima, uz primenu izvesnih većih opterećenja. $U$ ovom radu se razmatraju elementi postojanosti i pouzdanosti a predlaže se i potreban postupak izbora projektovanja, planiranja i proveravanju pouzdanosti rezultata procesa. Koristeći ovaj izbor ovde su prikazani postupci projektovanja, planiranja i proveravanja pouzdanosti izvesnih rezultata procesa.

Ključne reči: Inženjerstvo sistema; Inženjerstvo pouzdanosti; Pouzdanost. 